\begin{tabular}{l|l}
\hline Votaice & $\begin{array}{l}\text { e-ISSN: } 2655-9404 \\
\text { DOI: } 10.20473 / \text { ntr.v2i2.13226 }\end{array}$ \\
\hline
\end{tabular}

Article history: Submitted 13 May 2019; Accepted 28 May 2019; Available online 1 June 2019.

\title{
Akibat Hukum Pelanggaran Legitieme Portie Melalui Akta Wasiat Menurut Burgelijk Wetboek (Studi Kasus Putusan Nomor 3109 K/ PDT/2015)
}

\author{
Fisuda Alifa Mimiamanda Radinda dan Ricka Auliaty Fathonah \\ radinda.wanda@gmail.com \\ Universitas Airlangga
}

\begin{abstract}
The purposes of this article are to know the legal consequences if the legitimate rights of Portie's heirs are violated due to the will of the heir. In verdict Number 3109 K/PDT/2015, there are inheritors who leave a will in which the testament contains the distribution of the property of the heir. With the will of the will, one of the heirs feels legitimately his portraiture becomes infringed. Basically every heir has a legitimate portie right that can not be excluded by anything including a will. This research is normative legal research particulary prescriptive research. The data research are in the form of primary materials and secondary materials. The technique of collecting legal materials is literature study technique. The approaches in this research are legislation approach, conceptual approach, and case approach. The conceptual framework is deductive. The results of this article indicate that the legal consequences arising from the violation of the legitimate portie rights are the cancellation of the will. Because the will is deemed defective and should be null and void.
\end{abstract}

Keywords: Testament Deed; Legitieme Portie; Legal Effect.

\begin{abstract}
Abstrak
Artikel ini bertujuan untuk mengetahui apa akibat hukum jika hak mutlak/hak legitieme portie ahli waris terlanggar karena akta wasiat Pewaris. Dalam putusan Nomor 3109 K/PDT/2015, terdapat pewaris yang meninggalkan surat wasiat yang mana surat wasiat tersebut berisi mengenai pembagian harta dari pewaris. Dengan adanya surat wasiat tersebut, salah satu dari ahli waris merasa legitieme portie nya menjadi terlanggar. Pada dasarnya setiap ahli waris memiliki hak legitieme portie yang tidak bisa disimpangi oleh apapun termasuk surat wasiat. Penelitian ini adalah penelitian hukum normatif bersifat preskriptif. Sumber bahan hukum penelitian yaitu berupa bahan-bahan primer dan bahan-bahan sekunder. Teknik pengumpulan bahan hukum dalam penelitian ini adalah teknik studi kepustakaan. Pendekatan dalam penelitian ini adalah pendekatan perundang-undangan, pendekaan konseptual, dan pendekatan kasus. Metode berpikir yang digunakan adalah metode berpikir deduktif. Hasil dari penelitian menunjukkan bahwa akibat hukum yang timbul dari pelanggaran hak mutlak/hak legitieme portie tersebut adalah pembatalan akta wasiat tersebut. Karena akta wasiat tersebut dianggap cacat dan sudah seharusnya batal demi hukum.
\end{abstract}

Kata Kunci: Akta Wasiat; Legitieme Portie; Akibat Hukum.

\section{Pendahuluan}

Hukum mengatur segala permasalahan di dalam kehidupan manusia salah satunya adalah Hukum Waris. Semua manusia yang hidup pasti akan mengalami mati, setelah kematian seseorang pasti timbul permasalahan tentang pembagian harta pewaris atau permasalahan yang lainnya yang berkaitan juga dengan ahli 
waris. Burgelijk Wetboek atau dalam bahasa Indonesia dikenal dengan Kitab Undang-Undang Hukum Perdata menurut sejarah adalah berasal dari Belanda yang diberlakukan di Indonesia berdasarkan asas konkordansi. Meskipun pada awalnya diberlakukan bagi orang keturunan Belanda, namun setelah Indonesia merdeka masyarakat Indonesia tetap menggunakan Burgelijk Wetboek untuk memecahkan masalah-masalah perdata. ${ }^{1}$

Bagi warga negara Indonesia keturunan Eropa (Belanda) dan Timur Asing Tionghoa, hukum Perdata (Burgelijk Wetboek) masih digunakan untuk menyelesaikan masalah harta kekayaan yang ditinggalkan oleh seseorang atau lebih yang telah meninggal dunia. Meskipun hukum itu sudah lama ada dan telah lama pula digunakan dalam kehidupan sehari-hari di Indonesia, namun penyelesaian terhadap harta kekayaan yang ditinggalkan oleh orang yang telah meninggal dunia tersebut sering menjadi masalah. ${ }^{2}$

Pewarisan menurut Burgelijk Wetboek dibedakan menjadi dua, yaitu Pewarisan secara ab intestato (ahli waris menurut Undang-Undang) dan pewarisan secara testamentair (ahli waris karena ditunjuk dalam surat wasiat atau testamen). ${ }^{3}$

Selain dari hal-hal yang dapat dilakukan oleh seseorang pewaris terhadap harta peninggalannya, jika ia telah meninggal dapat juga ia melakukan pemberianpemberian kepada seseorang pada waktu ia masih hidup. ${ }^{4}$

Menurut pasal 1666 Burgelijk Wetboek, hibah adalah suatu perjanjian dengan mana si penghibah, di waktu hidupnya, dengan cuma-cuma dan dengan tidak dapat ditarik kembali, menyerahkan sesuatu benda guna keperluan si penerima hibah yang menerima penyerahan itu.

Permasalahan mengenai pewarisan ini muncul ketika Pewaris meninggal dunia dan meninggalkan juga akta wasiat untuk para ahli warisnya. Yang menjadi

\footnotetext{
${ }^{1}$ Erie Hariyanto, 'Burgelijk Wetboek Menelusuri Sejarah Hukum Pemberlakuannya Di Indonesia' (2009) IV Al-Ihkâ.[150].

${ }^{2}$ Anisituas Amanat, Membagi Warisan Berdasarkan Pasal-Pasal Hukum Perdata BW (Raja Gravindo Persada 2001).[7].

${ }^{3}$ Effendi Perangin, Hukum Waris (Raja Gravindo Pustaka 2005).[4].

${ }^{4}$ Ali Afandi, Hukum Waris Hukum Keluarga Hukum Pembuktian (Rineka Cipta 2000).[30].
} 
permasalahan adalah ketika pembagian akta wasiat tersebut tidak sesuai dengan apa yang seharusnya dibagikan. Sehingga para ahli waris mempermasalahkan akta wasiat tersebut, karena ahli waris merasa memiliki hak legitieme portie.

Bagan 1. Putusan Nomor 3109 K/PDT/2015

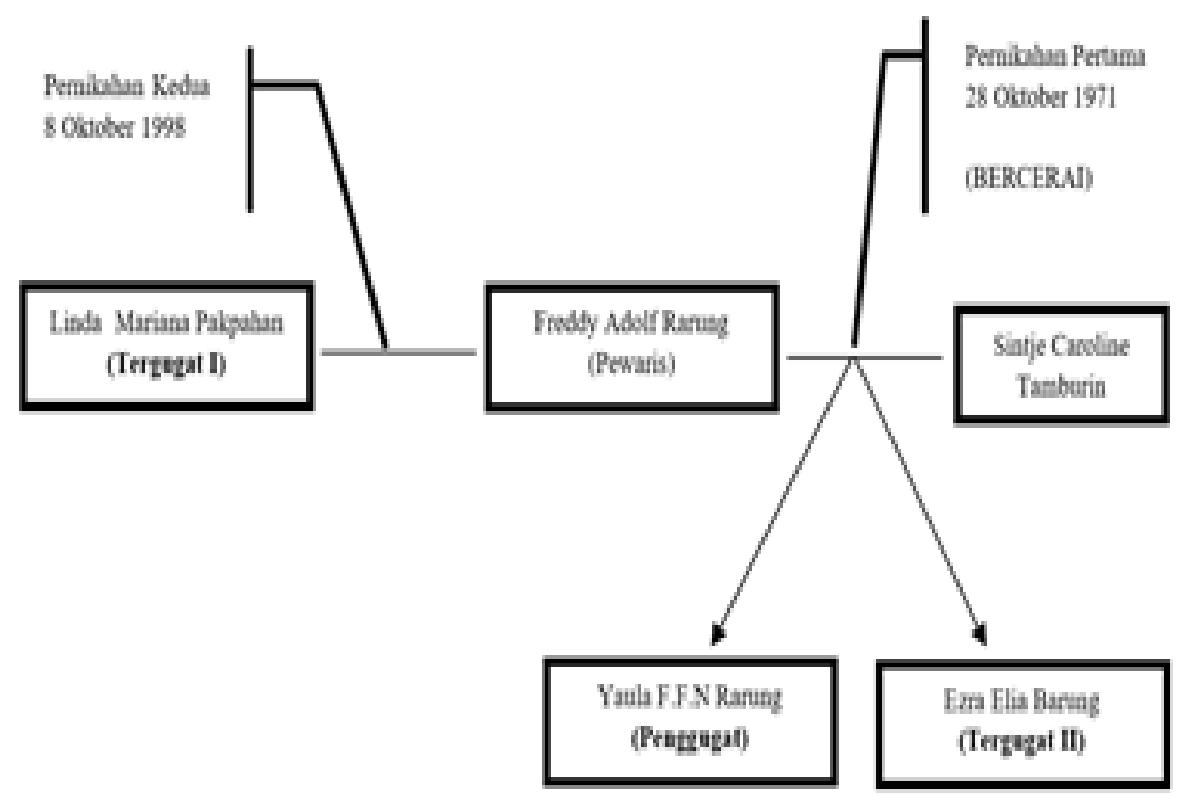

Jadi, dalam putusan Nomor 3109 K/PDT/2015, bahwa Freddy Adolf Rarung dengan Sintje Carolina Tamburian telah melangsungkan perkawinan pada tanggal 28 Oktober 1971, dari hasil perkawinan tersebut telah dikaruniai 2 orang anak perempuan dan Penggugat adalah salah satunya (anak yang paling sulung). Tanggal 10 November 1997, perkawinan Freddy A. Rarung dengan Sintje Carolina Tamburian tersebut berakhir dengan perceraian. Setelah perceraian antara Freddy A. Rarung dengan Sintje Carolina Tamburian sebagaimana disebutkan di atas, selanjutnya pada tanggal 8 Oktober 1998 Freddy A. Rarung melangsungkan perkawinan lagi dengan Linda Mariana Pakpahan (Tergugat). Kemudian pada tanggal 3 Januari 2013 Freddy A. Rarung meninggal dunia. Semasa hidup Freddy A. Rarung memiliki beberapa harta baik semasa pernikahan dengan Sintje Carolina Tamburian maupun semasa pernikahan dengan Linda Mariana Pakpahan (Tergugat) yang belum dibagi menurut hukum termasuk kepada Penggugat sendiri. Khusus harta peninggalan yang telah dibuatkan Akta Wasiat Nomor 2 tanggal 03 Juli 2006 oleh Freddy Adolf Rarung, dihadapan Notaris Dedy Suwandy, S.H., (Turut Tergugat) yaitu 
Linda Mariana Pakpahan (Tergugat I) dan Ezra Elia Barung (Tergugat II) sangat merugikan Penggugat sebagai ahli waris yang sah menurut hukum, karena dalam akta wasiat tersebut hanya Tergugat I dan Tergugat II yang mendapatkan bagian atas harta-harta tersebut, sedangkan Penggugat sama sekali tidak mendapatkan bagian sama sekali. Menurut hukum dalam seluruh harta peninggalan Alm. Freddy A. Rarung sebagaimana disebutkan di atas melekat hak/bagian mutlak (legitieme portie) Penggugat sebagai anak sah menurut hukum. Dalam kasus di atas diterapkan hukum waris barat (Burgelijk Wetbook) dengan asumsi bahwa Pewaris beragama selain Islam, sehingga hukum waris yang dapat digunakan adalah hukum waris barat atau hukum waris adat.

Menurut Pasal 913 Burgelijk Wetboek, bagian mutlak (legitieme portie) adalah suatu bagian dari harta peninggalan yang harus diberikan kepada ahli waris dalam garis lurus menurut undang-undang, terhadap bagian mana pewaris tidak diperbolehkan menguranginya dengan suatu pemberian di masa hidup atau pemberian dengan wasiat.

Namun pewaris mempunyai hak/wewenang atas barang-barang yang semasa hidupnya menjadi miliknya. Menurut pasal 874 Burgelijk Wetboek, suatu ketetapan yang sah yang diambil oleh pewaris yang dimaksud testament didahulukan terhadap ketentuan pewarisan berdasarkan Undang-Undang. Namun atas kemerdekaan pewaris, pembuat Undang-Undang membuat beberapa perkecualian, yang tak lain berarti pembatasan-pembatasannya. Bahwa suatu bagian sebanding tertentu dari hak waris ab-intestato mereka, tidak dapat diganggu gugat oleh pewaris, baik melalui suatu tindakan hukum semasa pewaris masih hidup, maupun melalui testament, kecuali atas persetujuan oleh yang bersangkutan. Bagian sebanding tertentu tersebut, yang dijamin oleh Undang-Undang, disebut legitieme portie. ${ }^{5}$

Meskipun pewaris memiliki kebebasan untuk membuat akta wasiat, pewaris tidak boleh mengabaikan hak mutlak/hak legitieme portie para ahli warisnya.

5 J.Satrio, Hukum Waris (Alumni 1992).[241-242]. 


\section{Rumusan Masalah}

Dari latar belakang di atas, penulis akan membahas mengenai akibat hukum pelanggaran hak legitieme portie melalui akta wasiat menurut Burgelijk Wetboek.

\section{Metode Penelitian}

Jenis penelitian yang digunakan dalam penelitian ini adalah penelitian hukum normatif. Menurut Soerjono Soekanto penelitian yuridis normatif adalah penelitian hukum yang dilakukan dengan cara meneliti bahan pustaka atau bahan hukum sekunder sebagai bahan dasar untuk diteliti dengan cara mengadakan penelusuran terhadap peraturan-peraturan dan literatur-literatur yang berkaitan dengan permasalahan yang diteliti.6 Penelitian yuridis normatif ini dilakukan untuk menjelaskan dan menganalisis permasalahan akibat hukum pelanggaran hak legitieme portie karena akta wasiat menurut Burgelijk Wetboek. Penelitian ini menggunakan pendekatan perundang-undangan (statute approach), pendekaan konseptual (conceptual approach), dan pendekatan kasus (case approach).

\section{Pengertian Akta Wasiat}

Hukum waris menurut Burgelijk Wetboek diatur dalam buku kedua bab 13, dalam Pasal 875 Burgelijk Wetboek, secara tegas dijelaskan pengertian tentang surat wasiat, yaitu: "Surat wasiat atau testament adalah suatu akta yang memuat pernyataan seseorang tentang apa yang dikehendakinya akan terjadi setelah ia meninggal dunia dan dapat dicabut kembali”.

Dalam pembuatan surat wasiat ini harus memperhatikan ketentuan bahwa pembuat wasiat harus menyatakan kehendaknya yang berupa amanat terakhir ini secara lisan maupun tulisan dihadapan notaris dan saksi-saksi. Dalam surat wasiat, surat wasiat selalu dapat ditarik kembali oleh pembuatnya. Hal ini disebabkan tindakan membuat surat wasiat adalah merupakan perbuatan.

6 Soerjono Soekanto dan Sri Mamudji, Penelitian Hukum Normatif(Suatu Tinjauan Singkat) (Rajawali Pers 2001).[13-14]. 


\section{Bentuk Surat Wasiat}

Burgelijk Wetboek menyebutkan tiga macam bentuk surat wasiat, yaitu:

a) Wasiat Olografis.

Pasal 931 Burgelijk Wetboek memberikan pengertian yaitu surat wasiat yang seluruhnya ditulis dengan tangan dan ditanda tangani oleh pewaris sendiri. Kemudian surat wasiat tersebut harus diserahkan untuk disimpan pada seorang notaris dan penyerahan kepada notaris ini ada dua cara, yaitu bisa dengan diserahkan dalam keadaan terbuka atau bisa juga dalam keadaan tertutup. Kedua cara penyerahan dan penyimpanan pada notaris yaitu sebagai berikut :

(1) Apabila surat wasiat diserahkan dalam keadaan terbuka maka dibuatlah akta notaris tentang penyerahan itu yang ditanda tangani oleh pewaris, saksi-saksi, dan juga notaris.

(2) Apabila surat wasiat diserahkan kepada notaris dalam keadaan tertutup, maka pewaris harus menuliskan kembali pada sampul dokumen itu bahwa surat tersebut berisikan wasiatnya dan harus menanda tangani keterangan itu dihadapan notaris dan saksi-saksi. Setelah itu pewaris harus membuat akta penyimpanan surat wasiat pada kertas yang berbeda.

Surat wasiat yang disimpan pada seorang notaris kekuatannya sama dengan surat wasiat yang dibuat dengan akta umum. Jika pewaris meninggal dunia dan wasiat diserahkan pada notaris dalam keadaan terbuka, maka segera penetapan dalam surat wasiat dapat dilaksanakan sebab notaris mengetahui isi surat wasiat tersebut. Sedangkan sebaliknya jika surat wasiat diserahkan dalam keadaan tertutup, maka pada saat pewaris meninggal dunia surat wasiat tidak dapat segera dilaksanakan sebab isi surat wasiat itu tidak dapat diketahui notaris sedangkan notaris dilarang membuka sendiri surat wasiat tersebut, maka untuk kepentingan itu surat wasiat harus diserahkan terlebih dahulu pada Balai Harta Peninggalan untuk membukanya.

b) Wasiat Umum

Menurut Pasal 931 Burgelijk Wetboek, surat wasiat yang dibuat oleh seorang notaris, dengan cara orang yang akan meninggalkan warisan itu 
menghadap notaris serta menyatakan kehendaknya dan memohon pada notaris agar dibuatkan akta notaris dengan dihadiri dua orang saksi. Pembuat surat wasiat harus menyampaikan sendiri kehendaknya itu dihadapan saksi-saksi. Hal itu tidak dapat dilakukan dengan perantaraan orang lain, baik anggota keluarganya, maupun notaris yang bersangkutan. Surat wasiat harus dibuat dalam bahasa yang dipergunakan oleh pewaris ketika menyampaikan kehendaknya, dengan syarat bahwa notaris dan saksi-saksi juga mengerti bahasa tersebut. Hal ini mengingat kesalahan dalam surat wasiat, biasanya tidak dapat diperbaiki lagi sebab hal itu baru diketahui setelah pewaris meninggal dunia. Jadi sedapat mungkin kesalahan formalitas itu harus diperkecil.

c) Wasiat Rahasia

Menurut Pasal 931 Burgelijk Wetboek, surat wasiat yang ditulis sendiri atau ditulis orang lain yang disuruhnya untuk menulis kehendak terakhirnya. Kemudian ia harus menanda tangani sendiri surat tersebut. Surat wasiat macam ini harus disampul dan disegel, kemudian diserahkan kepada notaris dengan dihadiri empat orang saksi. Penutupan dan penyegelan dapat juga dilakukan di hadapan notaris dan empat orang saksi. Selanjutnya pembuat wasiat harus membuat keterangan di hadapan notaris dan saksi-saksi bahwa yang termuat keterangan dalam sampul itu adalah surat wasiatnya yang ia tulis sendiri atau yang ditulis orang lain dan ia menanda tangani. Kemudian notaris membuat keterangan yang isinya membenarkan keterangan tersebut.

Setelah semua formalitas dipenuhi, surat wasiat itu selanjutnya harus disimpan pada notaris dan selanjutnya merupakan kewajiban notaris untuk memberitahukan adanya surat wasiat tersebut kepada orang-orang yang berkepentingan, apabila pembuat surat wasiat/peninggal warisan meninggal dunia. ${ }^{7}$

Dalam putusan Nomor $3109 \mathrm{~K} / \mathrm{PDT} / 2015$ tersebut, surat wasiat telah sah menurut hukum, karena dibuat sendiri oleh Freddy Adolf Rarung (semasa hidupnya) tanpa suatu paksaan atau perintah orang lain yang dibuat dihadapan

\footnotetext{
7 Eman Suparman, Intisari Hukum Waris Indonesia (Mandar Maju 1991).[90-92].
} 
Notaris Deddy Suwandy dan dihadiri oleh saksi-saksi yaitu Dedi Akurat Baskari dan Ny.Yanti Yusni. Jadi surat wasiat tersebut sah secara hukum tetapi batal demi hukum dikarenakan melanggar bagian mutlak legitimaris, yaitu anak sah almarhum yang bernama Youla F.F.N Barung (Penggugat).

\section{Pengertian Legitieme Portie}

Menurut Pasal 913 Burgelijk Wetboek, legitieme portie adalah suatu bagian dari harta peninggalan yang harus diberikan kepada ahli waris dalam garis lurus menurut undang-undang, terhadap bagian mana pewaris tidak diperbolehkan menguranginya dengan suatu pemberian di masa hidup atau pemberian dengan wasiat.

Menurut Pitlo, legitieme portie adalah bagian yang dijamin oleh UndangUndang dengan pengertian :

"Merupakan hak dia/mereka yang mempunyai kedudukan utama/istimewa dalam warisan. Hanya sanak saudara dalam garis lurus (bloedverwanten in de rechte lijn) dan merupakan ahli waris ab intestato saja yang berhak atas bagian yang dimaksud". 8

Yang dimaksud garis lurus yaitu garis lurus ke bawah atau garis lurus ke atas. Artinya, jika tidak ada ahli waris garis lurus ke bawah, ahli waris garis lurus ke atas berhak atas bagian mutlak. Ahli waris yang berhak atas bagian mutlak disebut legitimaris. Maksud diadakan ketentuan mengenai bagian mutlak adalah untuk melindungi hak para ahli waris dari perbuatan pewaris yang tidak bertanggug jawab. Misalnya, semua harta kekayaan dihibahkan dan diwasiatkan kepada orang lain menurut kemauannya sendiri tanpa memperhatikan kepentingan ahli warisnya. Padahal menurut undang-undang, para ahli waris mempunyai hak atas harta warisan. Undang-undang memandang ketentuan mengenai bagian mutlak sebagai pembatasan kebebasan seseorang membuat surat wasiat menurut kemauannya sendiri. Oleh karena itu, pengaturannya ditempatkan dalam bagian mengenai hak mewaris menurut surat wasiat. Akan tetapi, dalam pembahasan ini bagian mutlak ditempatkan dalam pokok bahasan mengenai harta warisan

8 Komar Andhasasmitha, Hukum, Harta Perkawinan Dan Waris Menurut Burgelijk Wetboek (Ikatan Notaris Indonesia 1987).[143]. 
sebab bagian mutlak hanya akan ada artinya apabila pewaris meninggalkan harta warisan dan wasiat.

Undang-undang memberikan syarat, jika seseorang menuntut atas bagian mutlak (legitieme portie), ia harus merupakan ahli waris ab intestato dalam garis lurus ke atas. ${ }^{9}$

Dalam putusan tersebut, Penggugat telah terlanggar legitieme portienya karena akta wasiat yang dibuat oleh Pewaris. Akibatnya, penggugat tidak mendapat pembagian harta warisan sama sekali. Padahal sudah seharusnya setiap ahli waris memiliki hak legitieme portie sendiri-sendiri. Dalam putusan tersebut penggugat sebagai anak sah pewaris yang berarti garis lurus ke bawah yang mana harus dilindungi bagian mutlaknya.

\section{Syarat Legitieme Portie}

Pewaris sebagai pemilik harta, mempunyai hak mutlak untuk mengatur apa saja yang dikehendaki atas hartanya. Ahli waris yang mempunyai hak mutlak atas bagian yang tidak tersedia dari harta warisan, disebut ahli waris legitimaris. Sedangkan bagian yang tidak tersedia dari harta warisan yang merupakan hak ahli waris legitimaris, dinamakan Legitieme Portie.

Syarat-syarat untuk dapat mempunyai hak atas legitieme portie adalah ahli waris yang memenuhi beberapa syarat tertentu yaitu: ${ }^{10}$

1) Mereka ahli waris dalam garis lurus yaitu keluarga dari garis lurus ke atas maupun ke bawah. Sehingga istri atau suami yang hidup lebih lama tidak termasuk ke dalam kelompok ahli waris yang mempunyai hak atas Legitieme Portie sekalipun dalam Pasal 852a Burgelijk Wetboek, hak waris mereka besarnya sama dengan anak.

2) Selanjutnya kata "ahli waris" dalam Pasal913 Burgelijk Wetboekmenunjukkan

\footnotetext{
9 Hartono Soerjopratiknjo, Hukum Waris Testamenter (Seksi Notariat Fakultas Hukum Universitas Gajah Mada 1984).[310].

10 NPS Law Office, 'Legitieme Portie' (NPS Law Office, 2014) <http://www.npslawoffice. com/legitieme-portie/> accessed 21 April 2019.
} 
pada kita bahwa yang mempunyai Legitieme Portie adalah orang yang benarbenar terpanggil untuk mewaris berdasarkan Undang-Undang pada saat matinya pewaris.

Dengan adanya bagian mutlak tersebut oleh Burgelijk Wetboek pewaris dibatasi kehendak terakhirnya terhadap harta peninggalan. Bagi legitimaris Undang-Undang telah menjamin, bahwa legitimaris akan menerima bagian minimum tertentu, yaitu bagian yang dijamin oleh Undang-Undang atau bagian mutlak. ${ }^{11}$

Bagian mutlak ini mengalahkan baik wasiat maupun hibah-hibah yang pernah dilakukan oleh pewaris yang mengakibatkan kurangnya bagian mutlak legitimaris.

Penafsiran Burgelijk Wetboek dengan adanya legitieme portie terhadap harta peninggalan yang ditinggalkan oleh pewaris, sebenarnya harta peninggalan terbagi dua bagian, yaitu : bagian tersedia dan bagian mutlak. Bagian tersedia adalah bagian yang dapat dikuasai oleh pewaris, dan dapat diberikan kepada siapa saja yang dikehendaki. Sedangkan bagian mutlak adalah bagian yang tidak dapat dikuasai oleh pewaris dan tidak dapat diberikan kepada ahli waris lain (pihak ketiga yang mewaris berdasarkan wasiat) selain ahli waris legitimaris, hal ini sudah secara tegas diatur di dalam Undang-Undang, yang mana bagian mutlak "harus" dimiliki oleh legitimaris, dengan ketentuan apabila legitimaris menuntut untuk mendapatkan haknya. Tetapi untuk memperoleh bagian mutlak itu tentunya harus sesuai dengan Burgelijk Wetboek dan hukum acara perdata di Indonesia. ${ }^{12}$

Dengan demikian dalam Putusan Pengadilan Nomor 3109 K/PDT/2015 tersebut sudah benar yaitu bahwa anak sah dari pewaris mengajukan gugatan untuk mendapatkan legitieme portie dari harta peninggalan pewaris. Akta wasiat yang sudah jelas dilanggar sehingga dalam Putusan Pengadilan menghitung kembali bagian masing-masing agar legitimaris mendapatkan bagian mutlaknya. Maka isi dari Akta Wasiat yang telah dibuat Pewaris dianggap tidak pernah terjadi. Setelah itu untuk memenuhi bagian mutlak diadakan penghitungan kembali harta peninggalan pewaris.

\footnotetext{
${ }^{11}$ Komar Andhasasmitha (n 8).Op.Cit.[143].

${ }_{12}$ Anisituas Amanat (n 2).Op.Cit.[68].
} 


\section{Besarnya bagian mutlak}

Menurut Pasal 914 Burgelijk Wetboek, bagian mutlak ahli waris ditetapkan sebagai berikut:

1) Apabila hanya ada satu orang anak sah, bagian mutlak adalah seperdua dari harta warisan yang diperolehnya tanpa surat wasiat.

2) Apabila ada dua orang anak sah, bagian mutlak anak adalah dua pertiga dari harta warisan yang diperolehnya tanpa surat wasiat.

3) Apabila ada tiga orang anak sah, bagian mutlak adalah tiga perempat dari harta warisan yang diperolehnya tanpa surat wasiat.

Cara menghitung besar bagian mutlak harus memerhatikan ketentuan Pasal 916 a Burgelijk Wetboek. Menurut ketentuan Pasal tersebut, dalam hal ada ahli waris mutlak dan ahli waris tidak mutlak, penghibahan harus tidak melanggar bagian mutlak yang ditentukan. Penentuan bagian mutlak itu tanpa memperhitungkan adanya ahli waris tidak mutlak. Apabila penghibahan itu melebihi jumlah bagian mutlak yang ditentukan tanpa memperhitungkan ahli waris tidak mutlak, kelebihannya dapat dituntut kembali oleh ahli waris mutlak. ${ }^{13}$

Bagian waris pada saat pelaksanaan wasiat tersebut menjelaskan bahwa, khusus harta peninggalan pada point 6 Nomor urut B1 sampai dengan B10 dibuatkan Akta Wasiat Nomor 2 tanggal 03 Juli 2006 oleh Freddy Adolf Rarung (Pewaris), yang berhak mendapatkan harta-harta tersebut hanya istri keduanya Linda Marina Pakpahan (tergugat I) dan anak sulungnya Ezra Elia Barung (tergugat II) dan harta Pewaris yang lainnya juga dalam penguasaan Tergugat I dan Tergugat II, sehingga anak pertama Pewaris Yaula F.F.N Rarung tidak mendapatkan bagian sama sekali. Karena menururt hukum dalam seluruh harta peninggalan Alm.Freddy Adolf Rarung melekat hak/bagian mutlak (legitieme portie) Penggugat sebagai anak yang sah menururt hukum, jadi kemudian amar Putusan Nomor 3109 K/PDT/2015 tersebut di atas, dilakukan penghitungan kembali oleh hakim atas apa yang sudah ditentukan oleh pewaris. Dari harta-harta yang sudah dituangkan dalam akta wasiat, dihitung

${ }_{13}$ Abdul kadir Muhammad, Hukum Dagang Tentang Surat-Surat Berharga (Citra Aditya Bakti 1998).[223]. 
bagian legitieme portie penggugat. Meskipun adanya surat wasiat, tidak merugikan salah satu ahli warisnya yang juga anak sah dari pewaris. Setelah legitieme portie terpenuhi maka akta wasiat tetap dijalankan, yaitu diberikan kepada pihak ketiga, istri kedua dari pewaris (Linda Mariana Pakpahan).

Dalam ketentuan Pasal 902 Burgelijk Wetboek, suami atau istri kedua atau selanjutnya, tidak boleh dengan surat wasiat diberi hibah hak milik atau sejumlah barang yang lebih besar dari bagian terkecil anak sah dari perkawinan pertama dan maksimum 1/4 (seperempat) dari harta peninggalan seluruhnya. Jadi Linda Mariana Pakpahan sebagai istri kedua tidak boleh mendapatkan lebih besar dari pengguat yaitu Youla F.F.N Barung sebagai anak sah almarhum dari perkawinan pertama. Walaupun dalam perkawinan Linda Mariana Pakpahan ada harta bersama maka Hakim yang berhak membagi dengan adil menurut hukum yang sah. Legitieme Portie atau bagian mutlak Youla F.F.N Barung sebagai anak sah tetap harus dipenuhi. Jadi setelah bagian mutlak legitimaris terpenuhi maka bagian bebas tersebut diserahkan kepada istri keduanya unruk menjalankan wasiat terakhir pewaris.

Dalam kasus tersebut, sebelum penggugat mengajukan gugatannya ke pengadilan, semua harta, properti dan usaha bahkan ATM milik pewaris dikuasai oleh tergugat I yaitu yaitu Linda Mariana Pakpahan yang juga istri sah kedua dari pewaris dan tergugat II Ezra Elis Barung yang juga sebagai anak sulung dari pewaris. Keduanya sebagai pendapat wasiat dari pewaris, yang mana wasiat tersebu batal demi hukum karena anak sah kedua dari pewaris tidak mendapatkan bagian mutlaknya bahkan tidak mendapatkan harta sama sekali.

Kemudian penggugat sebagai anak sah Freddy A. Rarung menurut hukum, memohon kepada Pengadilan Negeri Jakarta Utara, apabila Tergugat I dan Tergugat II tidak mau secara sukarela untuk melaksanakan pembagian secara hukum atas bagian mutlak (legitieme portie) maka, penggugat memohon kepada Pengadilan untuk dilaksanakan pelelangan umum atas seluruh harta peninggalan Alm.Freddy A. Rarung, serta pembagiannya secara adil menurut hukum untuk memenuhi hak/ bagian mutlak (legitieme portie) pengguat. Jadi ahli waris Almarhum Freddy Adolf Rarung yaitu: 
1. Linda Mariana Pakpahan (Tergugat I)

2. $\quad$ Ezra Elia Rarung (Tergugat II)

3. Youla FFN Rarung (Penggugat)

Dalam kasasi tergugat I yang juga sebagai istri kedua pewaris mendapat separuh harta gono-gini vide Pasal 181 Burgelijk Wetboek, yaitu sebesar maksimum $1 / 4$, berarti harta peninggalan yang terdiri dari "harta bawaan" dan "harta bersama" itu masuk sebagai boedel warisan adalah sebesar 4/4-1/4=3/4, menjadi hak segenap para ahli waris. Maka apabila mengikuti pertimbangan hukum judex facti, maka Tergugat I, Tergugat II, dan Penggugat masing-masing mendapatkan $3 / 4: 3=1 / 4$.

Sementara Tergugat II dan Penggugat adalah ahli waris yang sah dan sepenuhnya berhak atas harta bawaan almarhum menjadi berkurang haknya oleh sebab secara komulatif Tergugat I selaku istri kedua mendapat total bagian 1/4 $+1 / 4=2 / 4$.

Tetapi pembagian diatas salah, karena dalam putusan Mahkamah Agung bahwa judex facti tersebut diatas melanggar Pasal 852a Burgelijk Wetboek, yang berbunyi:

"Dalam hal warisan dan seorang suami atau isteri yang telah meninggal lebih dahulu, suami atau isteri yang ditinggal mati, dalam menerapkan ketentuan-ketentuan bab ini, disamakan dengan seorang anak sah dan orang yang meninggal, dengan pengertian bahwa bila perkawinan suami isteri itu adalah perkawinan kedua atau selanjutnya, dan dari perkawinan yang dulu ada anak-anak atau keturunan-keturunan anak-anak itu, suami atau isteri yang baru tidak boleh mewarisi lebih dan bagian terkecil yang diterima oleh salah seorang dan anak-anak itu, atau oleh semua keturunan penggantinya bila ia meninggal lebih dahulu, dan bagaimanapun juga bagian warisan isteri atau suami itu tidak boleh melebihi seperempat dan harta peninggalan si pewaris".

Jadi menurut hukum waris perdata, Tergugat I hanya memiliki hak maksimum sebesar $1 / 4$ bagian dari peninggalan Pewaris. sehingga Tergugat I yang juga anak kedua dari pewaris dan Penggugat sebagai anak sulung pewaris berhak atas $3 / 4$ dari boedel warisan, dimana masing-masing mendapatkan bagian sebesar $3 / 4: 2=3 / 8$ dari harta peninggalan pewaris. Jadi bagian masing-masing :

1. Linda Mariana Pakpahan (Tergugat I) : $2 / 8$

2. Ezra Elia Rarung (Tergugat II) $\quad: 3 / 8$

3. Youla FFN Rarung (Penggugat) $\quad: 3 / 8$ 


\section{Kesimpulan}

Di dalam putusan disebutkan bahwa benar Penggugat (Youla FFN Rarung) merupakan ahli waris dari Pewaris dan berhak atas legitieme portie. Pewaris meninggalkan wasiat yang mana berisi mengenai pembagian harta untuk Tergugat I dan Tergugat II. Penggugat merasa dirugikan karena tidak disebut di dalam wasiat tersebut serta harta pewaris yang lain berada dalam kekuasaan Tergugat I dan Tergugat II. Akibat hukum dari adanya Putusan Nomor 3109 K/PDT/2015 tersebut adalah wasiat menjadi batal demi hukum, namun tidak berarti wasiat itu tidak dijalankan maka dari itu telah dilakukan perhitungan legitieme portie oleh hakim agar legitieme portie Penggugat bisa terpenuhi.

\section{Daftar Pustaka}

\section{Buku}

Ali Afandi, Hukum Waris Hukum Keluarga Hukum Pembuktian (Rineka Cipta 2000).

Anisituas Amanat, Membagi Warisan Berdasarkan Pasal-Pasal Hukum Perdata $B W$ (Raja Gravindo Persada 2001).

Effendi Perangin, Hukum Waris (Raja Gravindo Pustaka 2005).

Eman Suparman, Intisari Hukum Waris Indonesia (Mandar Maju 1991).

Hartono Soerjopratiknjo, Hukum Waris Testamenter (Seksi Notariat Fakultas Hukum Universitas Gajah Mada 1984).

J.Satrio, Hukum Waris (Alumni 1992).

Komar Andhasasmitha, Hukum, Harta Perkawinan Dan Waris Menurut Burgelijk Wetboek (Ikatan Notaris Indonesia 1987).

Mamudji SS dan S, Penelitian Hukum Normatif (Suatu Tinjauan Singkat) (Rajawali Pers 2001).

Muhammad A kadir, Hukum Dagang Tentang Surat-Surat Berharga (Citra Aditya Bakti 1998). 


\section{Jurnal}

Erie Hariyanto, 'Burgelijk Wetboek Menelusuri Sejarah Hukum Pemberlakuannya Di Indonesia' (2009) IV Al-Ihkâ

\section{Laman}

NPS Law Office, 'Legitieme Portie' (NPS Law Office, 2014) <http://www. npslawoffice.com/legitieme-portie/> accessed 21 April 2019

HOW TO CITE: Fisuda Alifa Mimiamanda Radinda dan Ricka Auliaty Fathonah, 'Akibat Hukum Pelanggaran Legitieme Portie Melalui Akta Wasiat Menurut Burgelijk Wetboek (Studi Kasus Putusan Nomor 3109 K/PDT/2015)' (2019) Vol. 2 No. 2 Notaire. 
--Halaman ini sengaja dibiarkan kosong-- 